\title{
The Different Effect of Instructional Approaches of Physical Education and Students' Motor Capability on Students' Physical Fitness
}

\author{
Erizal Nurmai
}

\author{
Faculty of Sport Science, Universitas Negeri Padang, Indonesia \\ *Corresponding author. Email: erizalnurmai@fik.unp.ac.id
}

\begin{abstract}
This research is intended to find out the effect of instructional approaches of Physical Education and students' motor capability on students' physical fitness. This research was conducted to grade 4, 5, and 6 of Primary School No. 10 (National Standard Primary School) of Kuranji, Padang, in the academic year or 2010/2011 using $2 \times 2$ factorial research design.The populations are grade 4, 5, and 6 with the total of 172 students and 64 of them were chosen randomly to be the samples. The data were collected through physical fitness test and motor capability test, and then were analyzed by two-way ANAVA of $2 \times 2$.The data analysis and interpretation indicate that: (1) in general, the result of students' physical fitness taught by task-based instructional approach is better than those taught by command-based one; (2) there is an interaction of instructional approach and motor capability on the improvement of students' fitness of National Standard Primary School; (3) the students with high motor capability taught by task-based instructional approach result in higher physical fitness than those with low motor capability taught by command-based one; (4) the students with low motor capability taught by task-based instructional approach result in lower physical fitness than those taught by command-based one.
\end{abstract}

\section{Keywords: Physical Fitness, Motor Capability, Task-Based and Command Based}

\section{INTRODUCTION}

One of the important factors that needs to be considered, yet often neglected, for the improvement of education quality is the physical quality improvement. This is because "the physical quality improvement is fundamental to the growth and development of a nation" [1]. To attain the quality education, there are two important points to be noted. The first one is motor skill. The second one is physical fitness. Both of them can be obtained by doing sports and having physical education at schools. So, someone who has good physical fitness will attain good health, and it will also increase the work force performed on daily life then the work productivity will be well procured. On the other hand, a person with less physical fitness level will get his/her work capacity decreased. Therefore, it is necessary to start from the early age.

From the results of a national survey (2006), "it was found out that the students' level of physical fitness was very low, more specifically: $45.97 \%$ in low level; $10.71 \%$ in very low level; and only $37.66 \%$ in average level" [2]. These numbers indicate that the physical fitness is a serious problem faced by the students. The other influencing factor is the teachers' creativity on the use of approach (strategy); the approach (strategy) used sometimes does not fit the learning situation/context.

The other thing is possibly because the students go along on numerous school activities which have nothing to do with physical education. In terms of school activities, students often do the tasks given by the teachers. They also pursue some additional courses, such as courses in English, mathematics and other fields of study. Although they still have some free time, they use it to engage with their mobile phone and internet as well as to play games. As a consequence, the students can not use their time to do physical education activities both at school and at home. In fact, the activities of making moves and playing at the early age are very important and highly needed by the students. This is in accordance with the recommendation of UNESCO's Declaration Theory on Sport (1970) which states that students' physical activities should be for one-third (1/3) to one-sixth (1/6) of total school time. It means that the students should do physical activities in physical education at school for $1 / 3$ to $1 / 6$ hour every day.

Thus, "it is necessary to see the students' motor skills and to know their level of physical fitness related 
to health starting from elementary school. This would be associated with the learning process in terms of using suitable methodology to improve the students' physical fitness. The learning methodology using tasks and commands are the learning approach in elementary schools

In terms of performing the learning process, it can certainly be seen from the activities of teacher and students because there is direct interaction, similarly with how the method or approach is implemented [3]. In this case, a teacher needs to find out a suitable approach for the students' circumstances. In learning physical education, the students are expected to be active and the teacher is also supposed to creatively perform the learning process. Up to present, the physical education activities at schools have not run well. In this case, the teachers are deemed necessary to develop the learning through a suitable approach for the students' states, so it can improve the students' physical fitness, thinking ability, emotion, and skills in accordance with the goals that have been determined nationally.

The information from teachers and societies pointed out that the learning of physical education ran less effectively. Furthermore, some principals said that the physical fitness of grade IV to grade VI students was less in line with what has been expected. In fact, the government, teachers, and most of the parents have expected that the students' level of physical fitness increase after learning physical education at school. Nevertheless, it was not in accordance with what has been expected. "The Education Board said that most physical education teachers, in teaching, only focused on one approach and strived less for developing students' skills, and it was mostly focused only on the subject about the techniques for a certain sport. Furthermore, the teachers only gave the tasks to the students when the teachers did not attend the learning process' [4].

Based on the information presented above, due to the discrepancy between what occurred in the field and what has been expected, it was deemed necessary to do a study on the effect of method (approach) undertaken on the students' level of physical fitness. This study was directed to the approach in physical education learning in a elementary school related to the students' level of motor skills.

\section{METHOD}

This study is quasi-experimental in nature, which can test hypotheses about causality. In this study, there are two independent variables, two controlled attribute variables, and one dependent variable. The research design used was factorial design $2 \times 2$ bye level. The objective of this study was to find out: 1) the difference on the students' physical fitness between by using taskbased learning approach and by using command-based learning approach in physical education learning in elementary school, and to find more effective and efficient approach in learning, in accordance with learning objectives of physical education in elementary school; 2) whether there is/ there is no difference between the effect of task-based learning approach and that of command-based learning approach on the physical fitness of students who have high motor skills in physical education learning in elementary school; 3) whether there is/ there is no difference between the effect of task-based learning approach and that of command-based learning approach on the physical fitness of students who have low motor skills in physical education learning in elementary school; and 4) whether there is an interaction between physical education learning approach and motor skill on elementary school students' physical fitness.

The process of this study comprised: 1) approaching to the school to conduct try-out; 2) analyzing the try-out results; 3) determining population and sample; 4) collecting preliminary data followed by conducting the study; 5) conducting the study starting from October to November 2012 at SD-SN (Elementary school-National Standard) Sungai Sapih Kuranji Padang, 18 meetings with 3 (three) times a week treatments. The population was 172 male students from grade IV to grade VI who were 10 to 12 years old when the study was conducted. The sample was randomly selected; there were 64 students as the sample divided into two groups. Prior to sampling, a test was undertaken to determine attribute variable (motor skill). The lowest score to the highest score were determined, then the median was calculated; $50 \%$ of the score up was indicated as high motor skill group, and $50 \%$ of the score down was indicated as low motor skill group. The data were obtained from the tests of physical fitness and motor skill. The forms of tests undertaken were based on the theories. The technique of data analysis was using ANAVA bye level, 2X2 factorial research design. There were some instruments used in this study [5]. The first one was physical fitness test related to health: 1). "body composition, 2). muscle strength, 3). muscular endurance, 4). abnormalities, and heart-lung endurance. The second one was motor skill test to see the students' motor ability, namely: 1). coordination, 2). balance, 3). speed, 4). dexterity, 5). limb muscle explosive power, and 6). Accuracy" [6].

\section{RESULT}

Based on the results of Anava analysis, further test, and Tukey test, the hypotheses were wholly accepted. The explanation of the first hypothesis was that overall, the result of physical fitness test of the group taught by task-based approach was higher than that of the group taught by command-based learning approach in physical education in elementary school. Seen from the average score of physical fitness test of the groups, overall, the group taught by task-based approach in 
physical education was 238.94 while the average score of physical fitness test of the group taught by command-based learning approach was 235.25 or $238.94>235.25$. This indicated that overall the result of physical fitness test of the group taught by task-based approach was higher than the group taught by command-based learning approach. Thus, the implementation of task-based approach in physical education was proven to give more effective and efficient effect to the students' physical fitness, rather than by using command-based learning approach in the learning of physical education.

In the second hypothesis which stated that there is the effect of interaction between physical education learning approach and students' motor skill on elementary school students' physical fitness. Based on the calculation of variance analysis (ANAVA)-two paths, it was found that the proposed Ha was accepted empirically. Furthermore, the interaction between physical education learning approach and motor skill on elementary school students' physical fitness can be seen in the graph below:

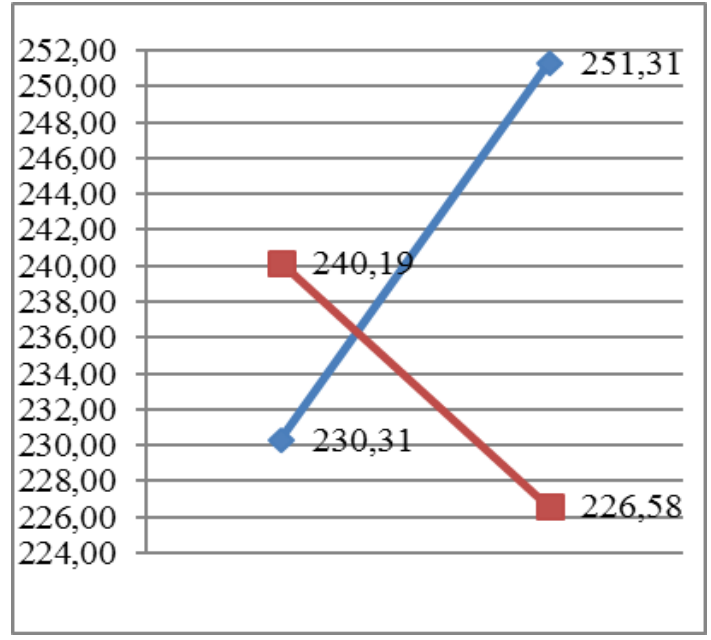

Graph: Interaction of Physical Education Learning Approach

Where :

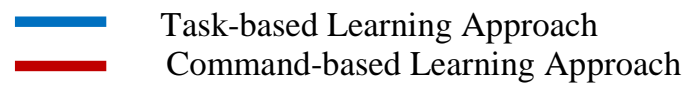

Based on the third hypothesis, the result of physical fitness test of the group of high motor skilled students who were taught by task-based learning approach was better than than that of students taught by commandbased learning approach in physical education in elementary school. The average score of physical fitness test of group of students with high motor skill taught by task-based learning approach was 251,31 while the average score of group of students with high motor skill taught by command-based learning approach was 240.19 or $251.31>240.19$. Thus it can be concluded that the result of physical fitness test of the group of students with high motor skill, who were taught by task-based learning approach was better than the group of students who were taught by commandbased learning approach in physical education in elementary school. Furthermore, related to the fourth hypothesis, the result of physical fitness test of the students with low motor skill who were taught by taskbased learning approach was lower than the students who were taught by command-based learning approach in physical education in elementary school. The average score of physical fitness test of the group of students taught by command-based learning approach was 230.31 , while the group of students who were taught by task-based learning approach was 226.58 or $230.31>$ 226.58. Thus, it can be concluded that the result of physical fitness test of group of students with low motor skill who were taught by using command-based learning approach was higher than the result of physical fitness test of the students who were taught by using task-based learning approach in hysical education in elementary school.

\section{CONCLUSION}

It was proved that, overall, the level of physical fitness of elementary school students taught by taskbased learning approach was better than those taught by command-based learning approach in physical education. The acceptance of this hypothesis as a whole means that in the learning of physical education for 10 to 12 year-old elementary school students, it is better to use task-based approach than command-based approach.

There was the effect of interaction between physical education learning approach and motor skill on the elementary school students' physical fitness. Therefore, it can be said that there is significant interaction between the students' motor skill and their physical fitness. Thus, the increase of students' physical fitness as the result of the learning approach undertaken will automatically increase their motor skill. This learning proses is implemented for 10 to 12 year-old elementary school students.

It is significantly proved that students with high motor skills, who are taught by task based learning approach, have higher outcome than physical fitness that are taught by a comand based learning approach. Therefore, to improve the RESULTS of students' physical fitness which have high motor skills, it is suggested to use task based learning approach in elementary school.

It is significantly proved that students who have low motor skills, who are taught by comand based learning approach have higher outcome than the result of physical fitness of students who are taught by task based learning approach. This indicates that to improve students' physical fitness improve who have low motor 
skills, it is highly reccomended to use command based learning apparoach at elementary school.

\section{REFERENCES}

[1] Goodway, Jacky. D.\&Branta, C.F, "Influence of Motor Skill on Fundamental Motor Skill Development of Disadvantagedpreschool chidren," Research Quaterly for Exercise and Sport. 2003.

[2] Gallahue, Davit L. \& John C. Ozmun, "Understanding Motor Development, Infant, Children, Adolescents, Adults," Indiana State University; Mc Graw Hill. Internasional Edition, 2006.

[3] Ateng, Abdul Kadir, “Azas dan Landasan Pendidikan Jasmani,” Jakarta: Depdikbud, pp, 90110. 2004.

[4] Carl Elibeth. Gabard, Le Blanc, and Susan Lowy, "Physical Education for Children," Building the Foundation New Jersey. USA; Practice-hall, Inc., Englewood Cl iffs. 2007.

[5] Consuelo, Dkk, Diterjemahkan oleh Alimuddin Tuwu, "Pengantar Metode Penelitian," Universitas Indonesia; UI-Press. 2003.

[6] Cholik, Toho Mutohir, "Gagasan Tentang Pendidikan Jasmani dan Olahraga," Surabaya; Unesa Universitas Press, pp, 26-45. 2002. 